\title{
Vitamin E Status in Newborn Lambs with Special Reference to the Effect of dl- $\alpha$-Tocopheryl Acetate Supplementation in Late Gestation *
}

\author{
By Bo Pehrson, Juhani Hakkarainen and Lennart Blomgren
}

The Experimental Station, Veterinary Institute, Skara and the Department of Clinical Nutrition, College of Veterinary Medicine, Swedish University of Agricultural Sciences, Uppsala, Sweden.

\section{Introduction}

It is well known that nutritional muscular dystrophy (NMD) can occur in selenium (Se) and vitamin $\mathrm{E}$ deficient animals and that these nutrients act synergistically in the prevention of NMD. There is evidence, however, that Se and vitamin $E$ each have a different effect in ruminants. Welch et al. (1960), Paulson et al. (1966) and Whanger et al.

\footnotetext{
* The investigation was supported by the Swedish Council for Forestry and Agricultural Research.
}

\begin{abstract}
Pehrson, B., J. Hakkarainen and L. Blomgren: Vitamin $\mathbf{E}$ status in newborn lambs with special reference to the effect of dl- $\alpha$-tocopheryl acetate supplementation in late gestation. Acta vet. scand. 1990, 31, 359-367. - Pregnant ewes were supplemented with dl- $\alpha$-tocopheryl acetate, either as a single intramuscular dose ( $500 \mathrm{mg}$ two weeks before lambing) or perorally ( $150 \mathrm{mg}$ daily during 3-4 weeks before lambing). Ewes without such a supplementation were controls.

The vitamin $E$ supplemented ewes had nearly twice as high vitamin $E$ ( $\alpha$-tocopherol) concentrations as the unsupplemented control ewes at lambing both in serum and in colostrum. The vitamin E concentration in colostrum was 5-11 higher than in milk 1 week after lambing.

Both supplementations somewhat increased the vitamin E serum concentration of the newborn lambs, but the increase was negligible in comparison with the effect produced by the consumption of colostrum. All lambs had very low serum conhigher serum values than the control lambs $24 \mathrm{~h}$ after birth.

The ewes had somewhat higher selenium status at birth than their offsprings when evaluated by glutathione peroxidase (GSH-Px) in the erythrocytes.

It seems reasonable that nutritional muscular degeneration may arise in newborn lambs with a normal selenium status if their vitamin $E$ status is critical, either because of an inadequate consumption of colostrum or because of a vitamin $E$ deficient diet during pregnancy with a low vitamin concentration of colostrum as a consequense.
\end{abstract}

nutritional muscular degeneration; feed supplementation; $\alpha$-tocopherol; placental barrier; selenium; sheep diseases; colostrum.

(1977) found that vitamin $E$ had a better prophylactic or therapeutic effect against NMD in lambs than Se, and Steele et al. (1980) and Maas et al. (1984) showed that NMD can occur in vitamin $\mathrm{E}$ deficient lambs with a normal Se status. In contrast, Muth et al. (1959) found that Se had a better prophylactic effect than vitamin $E$.

Se has been shown to cross the placental barrier readily in mice (Jacobsson \& Hansson 1965), dogs (Wright et al. 1951), cattle 
(Weiss et al. 1984) and sheep (Wright \& Bell 1964, Jacobsson \& Oksanen 1966). By ensuring that pregnant animals have adequate amounts of Se in their diet, Se deficiency in their offspring can be prevented. In contrast, vitamin E crosses the placental barrier much less readily, as is indicated by the fact that newborn animals have much lower serum $\alpha$-tocopherol levels than their dams (Scott 1978). In most investigations the vitamin $E$ analyses have been performed after the newborn animals have suckled, but $\mathrm{Bou}$ da et al. (1980) reported that before the intake of colostrum, the plasma concentration of vitamin $E$ in calves was only one fifth of that of their dams. There appears to be no report of the vitamin E status of lambs before the intake of colostrum, but experiments of Hidiroglou et al. (1972) indicate that the transfer of vitamin $E$ across the placenta of sheep is very limited. The vitamin $\mathrm{E}$ content of colostrum is higher than that of ordinary milk in women (Jansson 1981), sows (Nielsen et al. 1979), cows (Bouda et al. 1980) and ewes (Whiting et al. 1949).

The principal aim of this investigation was to measure the vitamin $E$ concentration in the serum of lambs before they had suckled. A secondary aim was to investigate whether a large dose of vitamin $E$ to the ewe during late pregnancy could increase the serum concentration of the vitamin in the newborn lambs. It was also possible to compare the $\mathrm{Se}$ status of ewes at parturition with that of their newborn lambs before suckling.

\section{Materials and methods}

The experiments were carried out on one farm with about 160 ewes of the Swedish native breed during the stable seasons of 1986 (Trial A) and 1987 (Trial B). The health of the herd was excellent and NMD had not occurred for many years. In both seasons most lambs were born in the middle of April. Du- ring the last few weeks of pregnancy all ewes were fed hay ad lib, $1 \mathrm{~kg}$ of grain, $0.1 \mathrm{~kg}$ of a commercial protein feed and minerals ad lib. The protein and mineral feeds contained selenium $(1.0$ and $10.0 \mathrm{mg} / \mathrm{kg}$, respectively as sodium selenite) and dl- $\alpha$-tocopheryl acetate (25 and $350 \mathrm{mg} / \mathrm{kg}$, respectively). After lambing, concentrates were fed according to the number of lambs per ewe (about $0.6 \mathrm{~kg}$ of grain and $0.1 \mathrm{~kg}$ of protein feed per lamb).

When the lambs were earmarked at an age of 3-4 days, $25 \mathrm{mg}$ of water-soluble dl- $\alpha$-tocopheryl acetate and $600 \mu \mathrm{g}$ of Se were given orally.

The Se status was evaluated by the determination of the acitivity of the enzyme glutathione peroxidase (GSH-Px) in erythrocytes, by the method of Paglia \& Valentine (1967). Se in colostrum and milk was determined according to Olson (1969).

Vitamin $E$ concentrations ( $\alpha$-tocopherol) in blood serum and milk were determined by high performance liquid chromatography (Pehrson \& Hakkarainen 1986, Hakkarainen \& Pehrson 1987).

Total lipids in serum were analysed by the method of Epstein et al. (1972).

Creatine kinase (CK) activity in serum was analysed by a kit reagent (Boehringer Mannheim).

Trial A. (Parenteral administration of vita$\min E$ )

On April 2, 1986 blood samples were taken from 12 randomly selected ewes in late pregnancy to evaluate the vitamin $E$ status of the herd. The herd was then divided into 2 groups, each consisting of about 80 ewes. The ewes in one group (supplemented group) were given a single intramuscular injection of $500 \mathrm{mg}$ watersoluble $\mathrm{dl}$ - $\alpha$-tocopheryl acetate. The other ewes were left untreated (control group). 
Nine ewes in each group which lambed between April 13-15 were selected at random. Immediately after they had lambed and before the lambs had been suckled, blood samples were taken from each of these ewes and from 1 of its lambs. These samples were analysed for vitamin $\mathrm{E}$ concentration and GSHPx activity. The CK activity was determined in serum from the lambs. The sampling procedure was repeated on the same animals 7 days later.

\section{Trial B. (Per oral administration of vitamin E)} On March 23, 1987 blood samples were taken from 14 ewes selected at random and the herd was divided into 2 equal groups each consisting of about 80 ewes. The ewes in one group were given a daily oral supplement of $150 \mathrm{mg}$ watersoluble dl- $\alpha$-tocopheryl acetate until they lambed (supplemented group), while the other ewes received no supplement (control group).

Ten of the ewes lambing between April 13-20 were selected at random from each group, and blood samples were taken from each ewe and from 1 of its lambs as in trial $A$; in addition samples were taken $24 \mathrm{~h}$ after lambing.

At the times of blood sampling, milk samples were taken and analysed for vitamin $\mathrm{E}$ and Se. The first $10 \mathrm{ml}$ of colostrum were re- jected on each occasion before the sample was taken for analysis.

\section{Results}

$\alpha$-tocopherol was the sole vitamin $\mathrm{E}$ isomer in milk and colostrum and the totally dominant isomer in serum. Only insignificant traces of $\gamma$-tocopherol could sometimes be detected in serum.

\section{Trial $A$}

Table 1 and 2 show that whether the concentrations of vitamin $E$ ( $\alpha$-tocopherol) were expressed as $\mathrm{mg} / \mathrm{l}$ serum or as $\mathrm{mg} / \mathrm{g}$ serum lipids, the ewes treated parenterally with $\mathrm{dl}-\alpha$ tocopheryl acetate 11 to 13 days before lambing had significantly higher serum tocopherol concentrations at lambing than the untreated ewes. The newborn lambs of the vitamin E supplemented ewes also had higher serum concentrations of vitamin $E$ before suckling than the lambs of untreated ewes, and the difference was significant when the concentration was expressed as $\mathrm{mg} / \mathrm{l}$ serum. However, all the lambs had very low vitamin $E$ levels in serum before suckling. One week later the values were 3-12 times greater.

The mean activities of CK in the serum of the lambs of the supplemented and control groups were not significantly different at lambing or 1 week later. All the values were

Table 1. Trial A. Effect of supplementation of vitamin E ( $500 \mathrm{mg} \alpha$-tocopheryl acetate intramuscularly) in late gestation on serum vitamin $\mathrm{E}$ values $(\mathrm{mg} / \mathrm{l})$ of ewes and their lambs at different times before and after lambing.

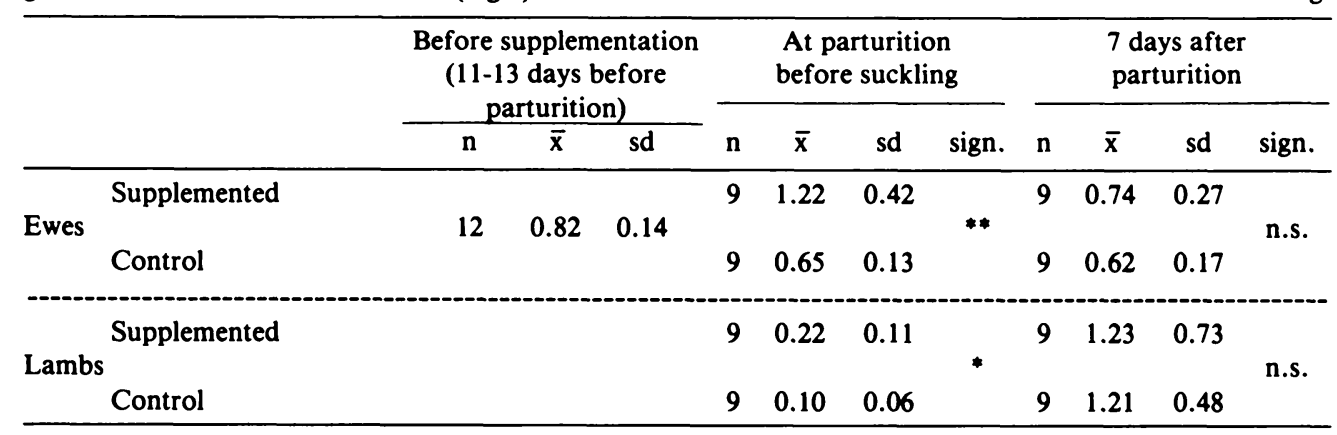


Table 2. Trial A. Effect of supplementation of vitamin E ( $500 \mathrm{mg} \alpha$-tocopheryl acetate intramuscularly) in late gestation on serum vitamin $\mathrm{E}$ values ( $\mathrm{mg} / \mathrm{g}$ lipid) of ewes and their lambs at different times before and after lambing.

\begin{tabular}{|c|c|c|c|c|c|c|c|c|c|c|c|c|}
\hline & & \multicolumn{3}{|c|}{$\begin{array}{l}\text { Before supplementation } \\
\text { (11-13 days before } \\
\text { parturition) }\end{array}$} & \multicolumn{4}{|c|}{$\begin{array}{l}\text { At parturition } \\
\text { before suckling }\end{array}$} & \multicolumn{4}{|c|}{$\begin{array}{l}7 \text { days after } \\
\text { parturition }\end{array}$} \\
\hline & & $\bar{n}$ & $\overline{\mathrm{x}}$ & sd & $\mathrm{n}$ & $\bar{x}$ & sd & sign. & $\mathrm{n}$ & $\overline{\mathbf{x}}$ & sd & sign. \\
\hline \multirow[b]{2}{*}{ Ewes } & Supplemented & & & & 9 & 0.50 & 0.15 & & 9 & 0.31 & 0.10 & \multirow[b]{2}{*}{ n.s. } \\
\hline & Control & 12 & 0.39 & 0.06 & 9 & 0.30 & 0.08 & * & 9 & 0.27 & 0.07 & \\
\hline \multirow{2}{*}{ Lambs } & Supplemented & & & & 9 & 0.18 & 0.09 & & 9 & 0.47 & 0.28 & \multirow[b]{2}{*}{ n.s. } \\
\hline & Control & & & & 9 & 0.11 & 0.06 & n.s. & 9 & 0.43 & 0.21 & \\
\hline
\end{tabular}

in the range $1-12 \mu \mathrm{kat} / \mathrm{l}$ and the highest value was found in a newborn lamb of the supplemented group. No clinical signs of NMD were observed.

There were no significant differences neither between ewes nor between lambs in the supplemented and control groups in terms of the GSH-Px activity in erythrocytes at lambing. When the groups were put together the GSH-Px activity was significantly (p $<0.001$ ) higher in the ewes than in their lambs before suckling $(\overline{\mathrm{x}}=2804 \pm$ sd 1131 and $\bar{x}=1655 \pm \operatorname{sd} 444 \mu \mathrm{kat} / \mathrm{l}$, respectively).

\section{Trial $B$}

The ewes which had been supplemented orally with dl- $\alpha$-tocopheryl acetate during the last 3-4 weeks of pregnancy had significantly higher serum tocopherol concentrations than the unsupplemented ewes, both at lambing and 1 week later (Tables 3 and 4). Their lambs had significantly higher levels of serum vitamin E 1 day after lambing than the control lambs, but not immediately after birth or 1 week later. The serum vitamin $\mathrm{E}$ concentrations in all lambs before suckling were very low.

The concentration of vitamin $\mathrm{E}$ in the first colostrum was 2-3 times as great as in the milk 1 day later, and the concentration in the milk had decreased by a further factor of 2-3 by 1 week after lambing (Figs. 1 and 2). At lambing and $24 \mathrm{~h}$ after lambing the ewes in the supplemented group had a mean milk vi-

Table 3. Trial B. Effect of supplementation of vitamin E (150 mg $\alpha$-tocopheryl acetate orally per day) in late gestation on serum vitamin $\mathrm{E}$ values $(\mathrm{mg} / \mathrm{l})$ of ewes and their lambs at different times before and after lambing.

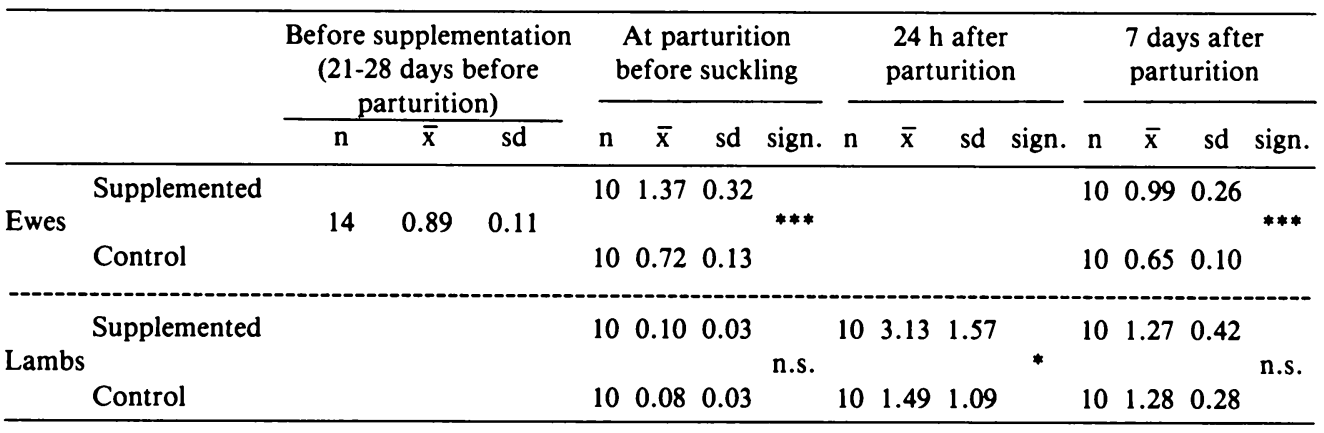


Table 4. Trial B. Effect of supplementation of vitamin E ( $150 \mathrm{mg} \alpha$-tocopheryl acetate orally per day) in late gestation on serum vitamin $\mathrm{E}$ values ( $\mathrm{mg} / \mathrm{g}$ lipid) of ewes and their lambs at different times before and after lambing.

\begin{tabular}{|c|c|c|c|c|c|c|c|c|c|c|c|c|c|c|c|c|}
\hline & & \multicolumn{3}{|c|}{$\begin{array}{l}\text { Before supplementation } \\
\text { (21-28 days before } \\
\text { parturition) }\end{array}$} & \multicolumn{4}{|c|}{$\begin{array}{l}\text { At parturition } \\
\text { before suckling }\end{array}$} & \multicolumn{4}{|c|}{$\begin{array}{l}24 \mathrm{~h} \text { after } \\
\text { parturition }\end{array}$} & \multicolumn{4}{|c|}{$\begin{array}{l}7 \text { days after } \\
\text { parturition }\end{array}$} \\
\hline & & $\mathrm{n}$ & $\overline{\mathrm{x}}$ & $s \mathrm{sd}$ & $\mathrm{n}$ & $\overline{\mathbf{x}}$ & sd & sign. & $\mathrm{n}$ & $\overline{\mathrm{x}}$ & sd & sign. & $\mathrm{n}$ & $\overline{\mathbf{x}}$ & sd & sign. \\
\hline \multirow{3}{*}{ Ewes } & Supplemented & & & & 10 & 0.47 & 0.11 & & & & & & 10 & 0.36 & 0.07 & \\
\hline & & 14 & 0.40 & 0.05 & & & & $* * *$ & & & & & & & & ** \\
\hline & Control & & & & 10 & 0.28 & 0.06 & & & & & & 10 & 0.28 & 0.04 & \\
\hline \multirow{3}{*}{ Lambs } & Supplemented & & & & 10 & 0.09 & 0.03 & & 10 & 0.61 & 0.24 & & 10 & 0.51 & 0.32 & \\
\hline & & & & & & & & n.s. & & & & ** & & & & n.s. \\
\hline & Control & & & & 10 & 0.07 & 0.02 & & 10 & 0.28 & 0.11 & & 10 & 0.43 & 0.09 & \\
\hline
\end{tabular}

tamin E concentration about twice that of the ewes in the control group, but the differences were statictically significant ( $p$ $<0.05$ ) only when the results were expressed as $\mu \mathrm{g} / \mathrm{g}$ lipid (Fig. 2). One week after lambing the concentrations were similar in both groups.

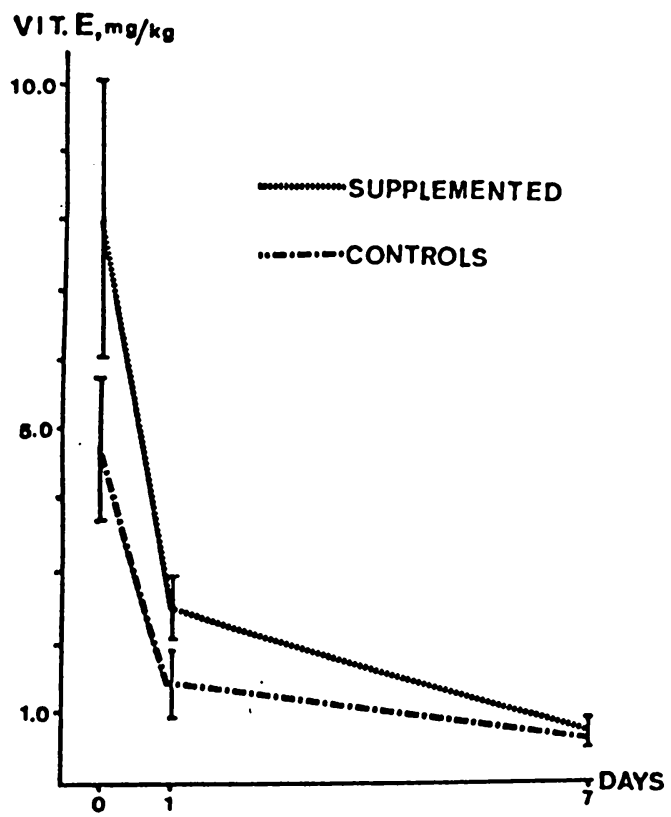

Figure 1. Mean ( \pm s.e.m.) concentrations $(\mathrm{mg} / \mathrm{kg}$ ) of vitamin $\mathrm{E}$ in milk from 10 ewes in Trial B at different times after lambing. day $0=$ first colostrum.
The first colostrum had about twice the Se content of the milk $24 \mathrm{~h}$ later, and 3.5 times the Se content of milk taken 1 week after lambing (Fig. 3).

The CK activity in the serum of the lambs increased from birth, when its mean and range were 2.2 and $1-8 \mu \mathrm{kat} / \mathrm{l}$, to 1 day later

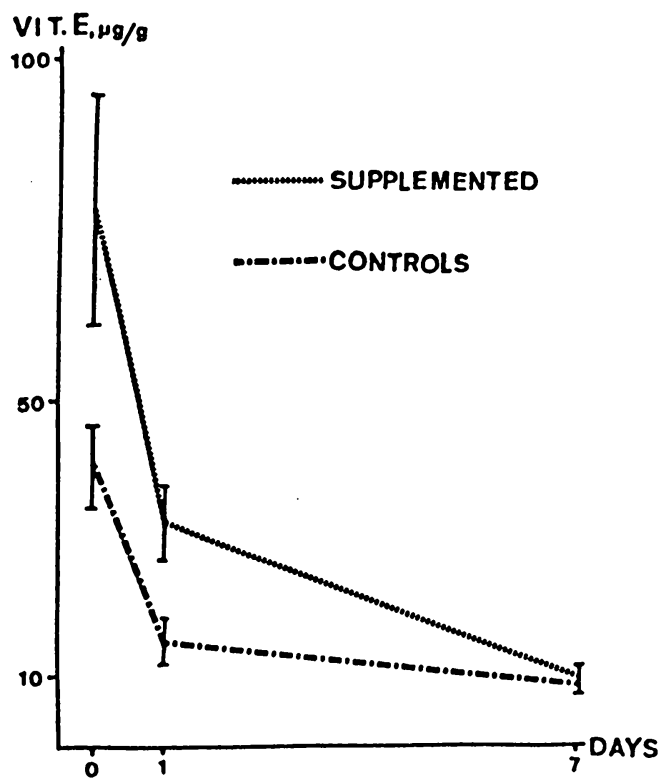

Figure 2. Mean ( \pm s.e.m.) ( $\mu \mathrm{g} / \mathrm{g}$ lipid) of vitamin $E$ in milk from 10 ewes in Trial $B$ at different times after lambing. Day $0=$ first colostrum. 


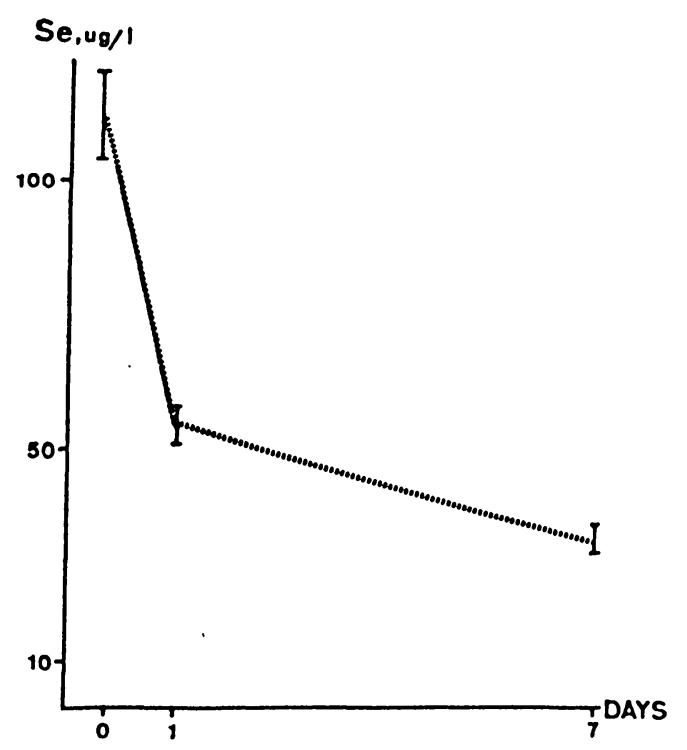

Figure 3. Mean ( \pm s.e.m.) $(\mu \mathrm{g} / \mathrm{l})$ of selenium in milk from 9 ewes in Trial B at different times after lambing. Data from the experimental and control groups have been combined. Day $0=$ first colostrum.

when the values were 14.5 and 5-37 $\mu \mathrm{kat} / \mathrm{l}$. When the lambs were 1 week old the values were 4.6 and $1-20 \mu \mathrm{kat} / \mathrm{l}$. No clinical signs of NMD were observed.

As in trial A, the GSH-Px activities at lambing were significantly higher $(p<0.05)$ in the ewes than in the lambs $(\bar{x}=1958 \pm$ sd 669 and $\bar{x}=1477 \pm \mathrm{sd} 527 \mu \mathrm{kat} / \mathrm{l}$, respectively).

\section{Discussion}

The supplementation of the diet of farm animals with Se, which has been officially permitted in Sweden since 1980, has reduced the prevalence of Se-vitamin E deficiency diseases in most animal species. However, the decrease in the incidence of NMD in sheep has been less than expected (Moksnes 1986). He presumed that the main reason was that many sheep consumed little of the Se-supplemented feed. However, since NMD can oc- cur in vitamin E deficient lambs with a normal Se status (Steel et al. 1980, Maas et al. 1984), it is possible that the vitamin E status is of main importance for the residual incidence of NMD. The disease is not uncommon in newborn lambs and the hypothetical aetiological role of vitamin $\mathrm{E}$ deficiency should be particularly significant in these animals, because of the poor transfer of vitamin $\mathrm{E}$ across the placental barrier in sheep (Hidiroglou 1972). Although Horton (1977) considered that intramuscularly administered vitamin $E$ was transferred across the placenta to some extent, his data - like most others relevant to the vitamin $E$ status of newborn animals - were based on samples taken after suckling had occurred. The much lower serum vitamin $\mathrm{E}$ concentrations found in calves before colostrum had been consumed, compared with the concentrations in their dams (Bouda et al. 1980) demonstrate that ruminants can be born with a low vitamin E status.

The results of the present investigation show that low serum vitamin E concentrations are normal in newborn lambs. The mean serum vitamin $\mathrm{E}$ concentrations in lambs before they had suckled $(0.08-0.22 \mathrm{mg} / \mathrm{l})$ were much lower than those considered to be necessary for avoiding the risk of clinical NMD in ruminants. The "safe « level has been reported to be at least $1.0 \mathrm{mg} / 1$ (McMurray \& Rice 1982, Øvernes et al. 1985) but even higher figures, from $1.5-2.0 \mathrm{mg} / \mathrm{l}$, have been proposed (Adams 1982, Maas et al. 1984, Morrill et al. 1987).

The feeding programme which was used in the present investigation is quite conventional in well-managed herds. Nevertheless, the mean serum vitamin $\mathrm{E}$ concentrations found in the ewes $(0.62-1.37 \mathrm{mg} / \mathrm{l}$ at different samplings) were lower than the »safe« figures given in the literature. One reason for this difference could be that analytical methods not 
based on HPLC tend to overestimate the vitamin E concentration. Moreover, several dietary factors can influence the requirement for vitamin $E$ to such an extent that it may be unsatisfactory to use serum $\alpha$-tocopherol concentration for estimating the vitamin E status of an animal. For example, Horwitt et al. (1972) proposed that it would be better to express the concentration as $\mathrm{mg}$ $\alpha$-tocopherol per $g$ serum lipid. However, our data (Tables 2 and 4) indicate clearly that this method of expressing the results does not imply any advantage. Because of the well-known relationship between the requirement of vitamin $E$ and polyunsaturated fatty acids in the ration (ie. Scott 1978), it may be more relevant to evaluate the vitamin E status of an animal in terms of the relationship between $\alpha$-tocopherol and polyunsaturated fatty acids. The data of McMurray \& Rice (1982) and Hakkarainen \& Pehrson (1987) indicate that it should be particularly worthwhile to measure the relationship between $\alpha$-tocopherol and linolenic acid (C 18:3).

However, even though expressing vitamin $\mathrm{E}$ status in terms of $\mathrm{mg} \alpha$-tocopherol per 1 serum may not be the ideal method, it seems certain that the lambs in the present investigation had very low serum $\alpha$-tocopherol concentrations at birth. There was a significantly higher mean concentration in the lambs born to ewes given a single parenteral dose of vitamin $\mathrm{E}$ in late gestation (Table 1), and a tendency towards a higher concentration in the lambs born to ewes given an oral vitamin $\mathrm{E}$ supplement in late pregnancy (Table 3). These higher levels indicate that it is possible to increase the transfer of vitamin $E$ across the placenta to some extent by supplementing the ewe with the vitamin during pregnancy. From a practical point of view, however, the increase in concentration achieved in this way was negligible in com- parison with the effect produced by the consumption of colostrum, which - provided that the ewes are fed a satisfactory diet contains plenty of vitamin $\mathrm{E}$. It is evident that the vitamin $E$ content of colostrum (Figs. 1 and 2), and consequently the vitamin E status of the lamb shortly after birth (Tables 1-4), was influenced by the level of vita$\min E$ in the diet of the ewe. It is reasonable to suppose that if a pregnant ewe has a poor vitamin $E$ status her colostrum will have a low vitamin E concentration. Young lambs with a normal Se status may then run the risk of NMD, either because they do not consume sufficient colostrum or because their dams are being fed a vitamin $\mathrm{E}$ deficient diet.

The serum CK activities of the lambs were slightly higher one day after lambing than at birth or one week later. This higher value may have been the result of the unaccustomed load placed on untrained muscles, and suggests that during their first few days lambs may be particularly prone to NMD. The serum vitamin $E$ concentrations of the lambs with the highest activities of CK $24 \mathrm{~h}$ after lambing ( $>20 \mu \mathrm{kat} / \mathrm{l} ; 2$ in each group) were close to the mean values of their respective groups.

The GSH-Px activity in erythrocytes is a good indicator of the Se status of ruminants (Carlström et al. 1979, Moksnes 1986). Using the correlation curve of Moksnes (1986), which is based on data obtained by using the GSH-Px method used in our laboratory, the mean GSH-Px values in the different groups at lambing correspond to $\mathrm{Se}$ concentrations of $210-320 \mathrm{ng} \mathrm{Se} / \mathrm{ml}$ whole blood. It is therefore evident that all the animals at that time had a satisfactory Se status. The higher GSH-Px activity in the ewes than in their offsprings at birth suggests that the transfer of Se across the placenta is restricted, in accordance with the results of Jacobs- 
son \& Oksanen (1966) and Wright \& Bell (1964). This restricted transfer will certainly be compensated for by the high Se content in colostrum (Fig. 3). Colostrum has been found to contain more Se than milk also in other ruminants (Koller et al. 1984).

In conclusion, these experiments show that lambs are born with a low vitamin E concentration in their serum, irrespective of the vitamin E content of the diet of the ewe during pregnancy. However, after the intake of colostrum the concentration of vitamin $\mathrm{E}$ will increase rapidly. An increase in the supply of vitamin $\mathrm{E}$ to the ewe during late pregnancy can increase the vitamin $\mathrm{E}$ content of her colostrum and, as a result, increase the serum vitamin $E$ concentration of the suckling lamb during its first days of life.

\section{References}

Adam CR: Feedlot cattle need supplemented vitamin E. Feedstuffs 1982, May, p. 24-25.

Bouda J, Jagos P, Dvorak $R$, Ondrova J: Vitamin E and $C$ in the blood plasma of cows and their calves fed from buckets. Acta vet. 1980, 49, 53-58.

Carlström G, Jönsson G, Pehrson B: An evaluation of selenium status of cattle in Sweden by means of glutathione peroxidase. Swedish J. agric. Res. 1979, 9, 43-46.

Epstein E, Baginski ES, Zak B: Extraction of lipids from serum and measurement of total serum lipids. Ann. clin. lab. Sci. 1972, 2, 244-254.

Hakkarainen J, Pehrson B: Vitamin E and polyunsaturated fatty acids in Swedish feedstuffs for cattle. Acta Agric. Scand. 1987, 37, 341-346.

Hidiroglou M, Jenkins KJ, Corner AH: Control of nutritional muscular dystrophy in lambs by vitamin E implantations. Canad. J. Anim. Sci. 1972, 52, 511-516.

Horton GMJ: Parenteral and oral administration of vitamin $\mathrm{E}$ and selenium to pregnant ewes. Animal Nutrition Events. F. Hoffman-LaRoche \& Co. AG Basel, Switzerland 1987.

Horwitt MK, Harvey CC, Dahm CH, Steacy MT: Relationship between tocopherol and serum lipid levels for determination of nutritional adequacy. Ann. N. Y. Acad. Sci. 1972, 203, 223-236.
Jacobsson SO, Hansson E: Distribution of selenium in mice studied by whole-body autoradiography after injection of $\mathrm{Se}^{75}$-sodium selenite. Acta vet. scand. 1965, 6, 287-298.

Jacobsson SO, Oksanen HE: The placental transmission of selenium in sheep. Acta vet. scand. 1966, 7, 66-76.

Jansson L: Quantitative determination of tocopherols with special reference to the vitamin $\mathrm{E}$ requirements of low birth weight infants. Thesis, Malmö, Sweden 1981.

Koller LD, Whitbeck GA, South PJ: Transplacental transfer and colostral concentrations of selenium in beef cattle. Amer. J. vet. Res. 1984, 45, 2507 2510.

Maas J, Bulgin MS, Anderson BC, Frye TM: Nutritional myodegeneration associated with vitamin E deficiency and normal selenium status in lambs. J. Amer. vet. med. Ass. 1984, 184, 201204.

McMurray $C H$, Rice DA: Vitamin E and selenium deficiency diseases. Irish vet. J. 1982, 36, 57-65.

Moksnes $K$ : Selenium supplementation in animal production in Norway. With special reference to sheep, attle and poultry. Thesis, National Veterinary Institute, Oslo, Norway 1986.

Morrill JL, Reddy PG: Effects of vitamin E on immune responses and performance of dairy calves. Roche Technical Symposium 1987, March 11, Dayton Beach, Florida, USA.

Muth OH, Oldfield JE, Schubert JR, Remmert LF: White muscle disease (myopathy) in lambs and calves. VI. Effects of selenium and vitamin E on lambs. Amer. J. vet. Res. 1959, 20, 231-234.

Nielsen HE, Danielsen $V$, Simesen MG, Gissel-Nielsen $G$, Hjarde $W$, Leth $T$, Basse $A$ : Selenium and vitamin $\mathrm{E}$ deficiency in pigs. I. Influence on growth and reproduction. Acta vet. scand. 1979, 20, 276-288.

Olson $O E$ : Fluorometric analysis of selenium in plants. J. Assoc. Off. Anal. Chem. 1969, 52, 627-634.

Øvernes $G$, Nymoen $U$, Froslie A: E-vitamin hjå sau og lam (Vitamin $E$ in ewes and lambs). Norsk Vet. tidskr. 1985, 97, 173-176.

Paglia DE, Valentine WN: Studies on the quantitative and qualitative characterization of erythrocyte glutathione peroxidase. J. lab. clin. Med. 1967, 70, 158-169. 
Paulson GD, Pope AL, Baumann CA: Lactic dehydrogenase isoenzymes in tissues and serum of normal and dystrophic lambs. Proc. Soc. exp. Biol. Med. 1966, 122, 321-324.

Pehrson B, Hakkarainen J: Vitamin E status of healthy Swedish cattle. Acta vet. scand. 1986, 27, 351-360.

Scott ML: Vitamin E. In: The Fat Soluble Vitamins. Handbook of Lipid Research. 2. Ed. DeLuca, H. E., Plenum Press. New York and London 1978, p. 133-210.

Steele P, Peet RL, Skirrow S, Hopkinson $W, M a-$ sters $H G$ : Low alfa-tocopherol levels in livers of weaner sheep with nutritional myopathy. Austr. vet. J. $1980,56,529-532$.

Whanger PD, Weswig PH, Schmitz JA, Oldfield JE: Effects of selenium and vitamin $E$ deficiencies on reproduction, growth, blood components, and tissue lesions in sheep fed purified diets. J. Nutr. 1977, 107, 1288-1297.

Weiss WP, Colenbrander VF, Cunningham MD: Maternal transfer and retention of supplemental selenium in neonatal calves. J. Dairy Sci. 1984, 67, 416-420.

Welch JG, Hoekstra WG, Pope AL, Phillips PH: Effects of feeding fish liver oil, vitamin $E$ and selenium to ewes upon the occurrence of muscular dystrophy in their lambs. J. Anim. Sci. 1960, 19, 620-628.

Whiting F, Willman JP, Loosli JK: Tocopherol (Vitamin E) deficiency among sheep fed natural feeds. J. Animal Sci. 1949, 8, 234-242.

Wright PL, Bell MC: Selenium 75 metabolism in the gestating ewe and fetal lamb: effects of dietary $\alpha$ tocopherol and selenium. J. Nutrition 1964, 84, 49-57.

Wright SW, Filer LJ, Mason KE: Vitamin E blood levels in premature and full term infants. Pediatrics, 1951, 7, 386-393.

\section{Sammenfattning}

E-vitaminstatus hos nyfödda lamm. Effekten av tillskott av dl- $\alpha$-tocopherylacetat till tackor under högdräktighet.

I en fårbesättning med vălordnad utfodring och mycket god djurhälsa gavs 2 grupper av högdrăktiga tackor dl- $\alpha$-tocopherylacetat- tillskott, antingen som intramuskulär engångsdos $(500 \mathrm{mg}) 2$ veckor fơre lamningen eller som dagligt peroralt tillskott (150 $\mathrm{mg}$ ) under 3-4 veckor forre lamningen. Som kontrollgrupper anvăndes tackor som inte erhobll nágot tillskott. Blodprov togs pá tackor och lamm vid lamning innan råmjölk hade konsumerets samt 1 dygn och 1 vecka senare. Mjölkprov togs från tackorna vid samma tillfällen. Tackorna som fick E-vitamintillskott hade vid lamningen 2 gånger högre E-vitaminhalt såväl $\mathrm{i}$ serum som $\mathrm{i}$ colostrum än kontrolltackorna. E-vitamininnehállet $i$ kolostrum var avsevärt högre än i mjölk som uttogs 1 dygn och 1 vecka efter lamningen.

E-vitamintillskotten resulterade visserligen $\mathrm{i}$ en okning av vitaminhalten i serum hos de nyfödda lammen, men denna var obetydlig i jämförelse med den som orsakades av kolostrumtillförseln. Samtliga lamm hade mycket låg E-vitaminhalt $i$ serum omedelbart efter födseln. Ett dygn senare hade halterna minst fyrdubblats.

Samtliga djur hade vid lamningen ett normalt selenstatus värderat genom bestämning av glutationperoxidas (GSH-Px) i erythrocyterna. Tackorna hade signifikant högre GSH-Px aktivitet än sina nyfodda lamm.

Det anses sannolikt att nutritionell muskeldegeneration kan uppstå hos nyfödda lamm med normalt selenstatus om deras E-vitaminstatus är otillräckligt till följd antingen av en otillrăcklig konsumtion av råmjolk eller av en E-vitaminbrist $i$ tackornas foderstat under dräktighet med åtföljande låg E-vitaminhalt i kolostrum.

(Received February 27, 1989; accepted October 27, 1989).

Reprints may be requested from: Bo Pehrsson, Experimental Station, Veterinary Institute, P. O. Box 234, S-53223 Skara, Sweden. 